С. В Недбай, О. І. Лігоцький, А. В. Носовський, Г. Г. Мелешко, О. А. Дудік

Державний науково-технічний центр з ядерноі та радіаційної безпеки, м. Київ, Україна

\section{Аналіз порушень у роботі АЕС України, що сталися протягом 2013 року}

Наведено аналіз потоку порушень, що сталися на АЕС України за рядом напрямів, які характеризують експлуатаційну безпеку. Виявлено тенденцію щодо зменшення кількості порушень, які виникли на АEC України, проте останні роки помилки персоналу стабільно становлять п'яту частину від загальної кількості безпосередніх причин виникнення аномальних подій. За результатами аналізу розроблено рекомендаці щодо покращення системи використання досвіду експлуатаціі та підвищення рівня експлуатаційної безпеки.

Ключові слова: AEC; порушення в роботі AEC; звіт; розслідування; статистичний аналіз; корінна причина; коригувальні заходи.

С. В Недбай, А. И. Лигоцкий, А. В. Носовский, А. Г. Мелешко, О. А. Дудик

Анализ потока нарушений в работе АЭС Украины, произошедших в 2013 году

Приведен анализ потока нарушений, произошедших на АЭС Украины, по ряду направлений, характеризующих эксплуатационную безопасность. Наблюдается тенденция по уменьшению количества нарушений, однако в последние годы ошибки персонала стабильно составляют пятую часть от общего количества непосредственных причин возникновения аномальных событий. По результатам анализа разработаны рекомендации по улучшению системы использования опыта эксплуатации и повышения уровня эксплуатационной безопасности.

Ключевые слова: АЭС; нарушения в работе АЭС; отчет; расследование; статистический анализ; коренная причина; корректирующие меры. (c) С. В Недбай, О.І.Лігоцький, А. В. Носовський, Г. Г. Мелешко, О. А. Дудік, 2014
$\mathrm{O}$ блік та аналіз порушень у роботі АЕC невід'ємна частина системи використання досвіду експлуатації, яка в свою чергу є складовою безпечної експлуатації АЕС. Для підтримання належного рівня безпечної експлуатації АЕС потрібно забезпечити проведення всебічного аналізу досвіду експлуатації та поширення позитивних уроків, визначених за результатами цього аналізу.

Така робота в рамках договору з Держатомрегулювання України [1], з використанням методики експертної оцінки, статистичної обробки даних та аналізу корінних причин, щорічно виконується Державним підприємством «Державний науково-технічний центр з ядерної та радіаційної безпеки» (ДНТЦ ЯРБ), починаючи з 1993 року, та є ключовою в аналізі досвіду експлуатації АЕС України.

Статистична оцінка потоку порушень у роботі АЕC проводиться з метою вивчення статистичних даних щодо порушень у роботі AEC, їх узагальнення та виявлення проблемних аспектів для подальшого аналізу.

За результатами аналізу порушень у роботі АЕС України, що сталися протягом 2013 року, розроблено рекомендації з покращення системи використання досвіду експлуатації та підвищення рівня експлуатаційної безпеки. Джерелом даних є звіти про розслідування порушень у роботі АЕС та інформаційна система «Порушення в роботі AEC».

Статистична оцінка порушень у роботі AЕC України. Протягом 2013 року в промисловій експлуатації перебували 15 енергоблоків АЕС, з яких 13 енергоблоків 3 реакторами типу ВВЕР-1000 та 2 енергоблоки (№№ 1, 2 Рівненської АЕС) 3 реакторами типу ВВЕР-440, а в режимі зняття з експлуатаціі - 3 енергоблоки на Державному спеціалізованому підприємстві «Чорнобильська АЕС» 3 реакторами типу РВПК (реактор великої потужності канальний).

У 2013 році виявлено 12 порушень у роботі АЕС України; порівняно з 2012 роком показник кількості порушень зменшився на 20 \%. Зокрема 11 порушень сталися на реакторах типу ВВЕР, що в 2 рази менше, ніж у 2009-2010 роках, одне - на реакторі типу РВПК (рис. 1). Середня кількість порушень на рік за останні п'ять років - 17; отже, у 2013 році кількість порушень менше середньої в 1,4 раза.

Середнє значення за 5 років такого показника, як потоки порушень (відношення кількості порушень до кількості енергоблоків) у роботі АЕС України, - 0,94 (пряма лінія на рис. 2). У 2013 році потік порушень - 0,67, що значно нижче, ніж у попередні роки. Похилою лінією зображено тренд потоку порушень у роботі АЕС за останні 5 років, звідки видно чітку тенденцію до зменшення цього показника.

3 аналізу розподілу порушень по майданчиках $A E C$ випливає (рис. 3), що на енергоблоках Рівненської (РАЕС) та Южно-Української АЕС (ЮУАЕС) кількість порушень у 2013 році порівняно 3 попереднім роком зменшилася в 2 рази, а на Запорізькій (ЗАЕС) та Хмельницькій АЕС (XАEC) залишилася на минулорічному рівні. Вперше з 2007 року сталося порушення в роботі на Чорнобильській AEC (ЧАЕС) (рис. 3). Жодного порушення в 2013 рощі не було зафіксовано на енергоблоках №№ 2, 5, 6 ЗАЕС, №№ 2, 4 PAEC, №№ 1, 3 ЮУАЕС, а на енергоблоці № 1 ЮУАЕС порушень не відбувалося взагалі за останні шість років, що пояснюється проведеними заходами з підготовки блока до продовження експлуатації.

Найбільше порушень на один енергоблок за останні п’ять років (табл. 1) сталося на енергоблоці № 2 ХАЕС (11 порушень), що вдвічі вище за середню кількість порушень на енергоблок за той самий період (5,6 порушень) та майже втричі, ніж на енергоблоці № 4 РАЕС, який введено 


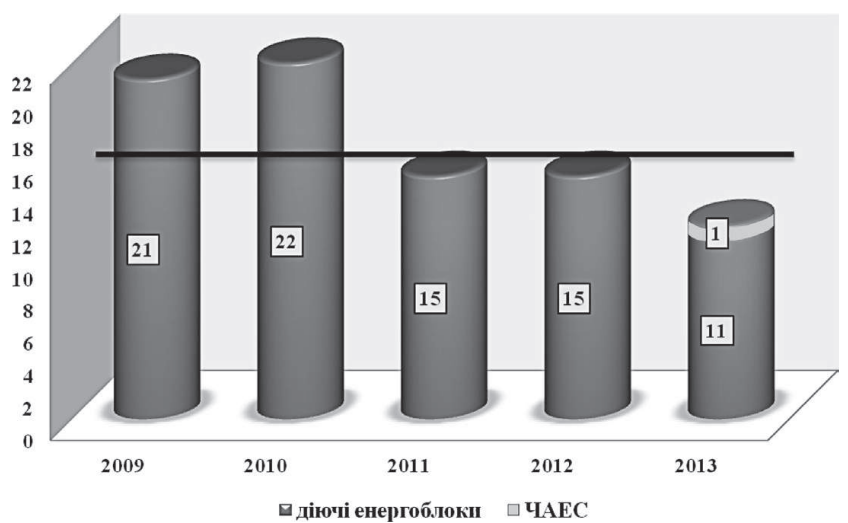

Рис. 1. Кількість порушень у роботі АЕС України в 2009-2013 роках

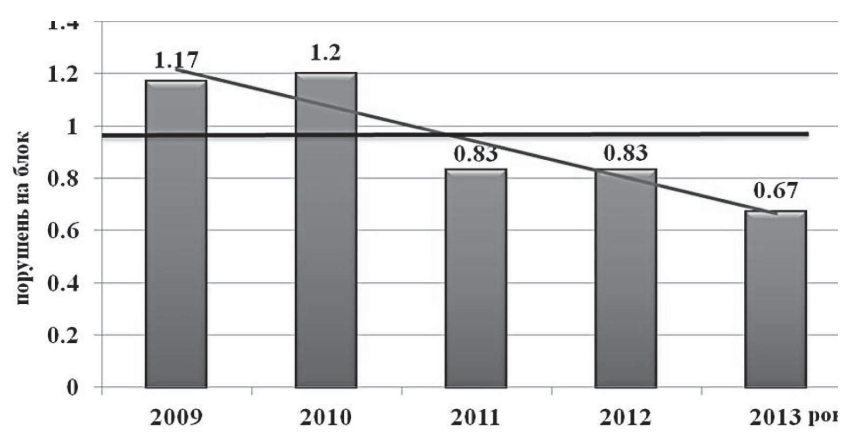

Рис. 2. Потік порушень у роботі АЕС України в 2009-2013 роках

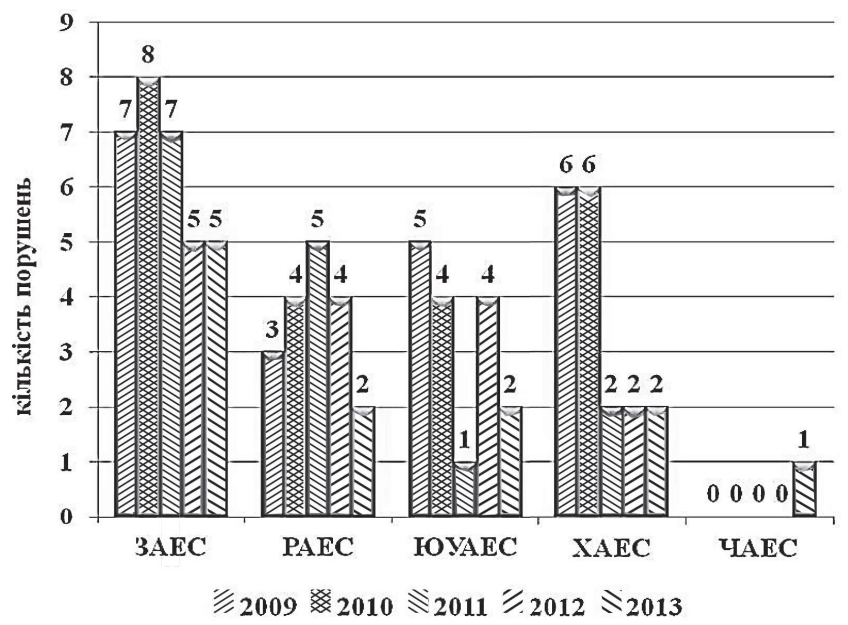

Рис. 3. Розподіл порушень по майданчиках AEC у 2009-2013 роках

Таблиия 1. Загальна (підсумкова) кількість порушень у роботі АЕС за 2009-2013 роки

\begin{tabular}{|c|c|c|c|c|c|c|c|c|c|c|c|c|c|c|}
\hline \multicolumn{10}{|c|}{ Енергоблоки AЕC } \\
\hline $\mathbf{1}$ & $\mathbf{2}$ & $\mathbf{3}$ & $\mathbf{4}$ & $\mathbf{5}$ & $\mathbf{6}$ & $\mathbf{1}$ & $\mathbf{2}$ & $\mathbf{3}$ & $\mathbf{4}$ & $\mathbf{1}$ & $\mathbf{2}$ & $\mathbf{3}$ & $\mathbf{1}$ & $\mathbf{2}$ \\
\hline 5 & 9 & 5 & 5 & 3 & 5 & 2 & 3 & 9 & 4 & 0 & 9 & 7 & 7 & 11 \\
\hline
\end{tabular}

в експлуатацію в тому ж році, що і № 2 ХАЕС. Отже, треба проаналізувати причини великої кількості порушень на енергоблоці № 2 ХАЕС (порівняно $з$ енергоблоком № 4 РАЕС), самі порушення, виявити негативні фактори, що спричинили їх, та розробити коригувальні заходи щодо їх виправлення.

Оскільки на кожному майданчику АЕС експлуатується різна кількість енергоблоків, більш об'єктивну картину дає такий показник, як середня кількість порушень на один енергоблок, тобто відношення кількості порушень до кількості енергоблоків, що експлуатуються на окремій АЕС. У 2013 році цей показник становив:

$\begin{array}{ccc}\text { AЕC } & \begin{array}{c}\text { Відношення кількості } \\ \text { порушень до кількості } \\ \text { енергоблоків }\end{array} & \begin{array}{c}\text { Середня кількість } \\ \text { порушень на один } \\ \text { енергоблок }\end{array} \\ \text { ЗАЕС } & 5 / 6 & 0,83 \\ \text { РАЕС } & 2 / 4 & 0,50 \\ \text { ЮУАЕС } & 2 / 3 & 0,67 \\ \text { ХАЕС } & 2 / 2 & 1,00 \\ \text { ЧАЕС } & 1 / 3 & 0,33\end{array}$

За типами реакторної установки (РУ) енергоблоки України розподіляються на три групи: енергоблоки з реакторами типу ВВЕР-1000 (13 енергоблоків), ВВЕР-440 (2 енергоблоки) та РВПК-1000 (3 енергоблоки). Розподіл середньої кількості порушень на один енергоблок по окремих типах РУ наведено на рис. 4.

Середня кількість порушень на енергоблоках з реакторами типу ВВЕР-1000, незважаючи на зниження показника в 1,5 раза, залишається вищою, ніж на енергоблоках з реакторами типу ВВЕР-440, де показник, порівняно 3 минулим роком, зріс.

У 2013 році в Україні за шкалою İНЕС [2] яка є всесвітнім інструментом для інформування населення про значимість ядерних і радіологічних подій для безпеки, не було порушень вище рівня «нижче шкали/рівень “0”» (не суттєво для безпеки, рис. 5).

Порушення в роботі АEC залежно від ознак $і$ наслідків класифікуються однією з категорій, що наведені в [1, додаток 1]. Розподіл порушень за наслідками в 2009-2013 роках на діючих енергоблоках наведено на рис. 6.

Кількість порушень категорії П05 (зупинення РУ або відключення енергоблока від мережі) становить $18 \%$, шо в 3,7 раза менше, ніж торік. Але, на відміну від 2012 року, значно зросла (більш як у 5 разів) частка порушень категорії

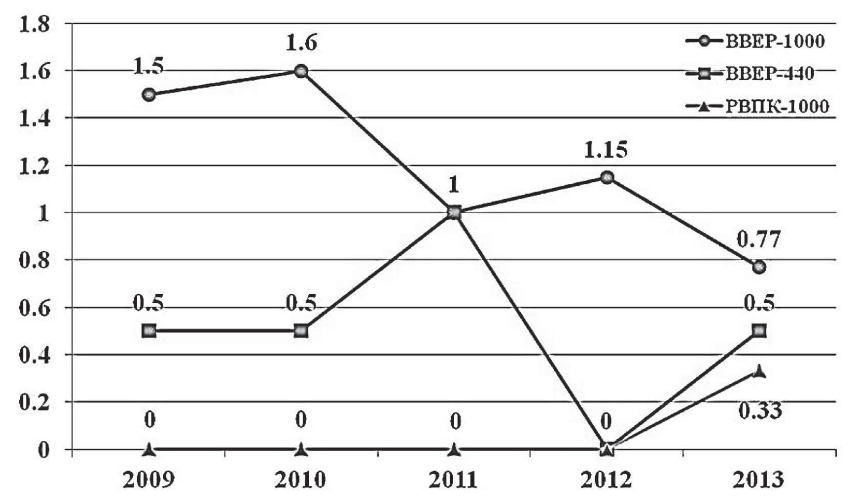

Рис. 4. Розподіл середньої кількості порушень на один енергоблок за типами РУ 


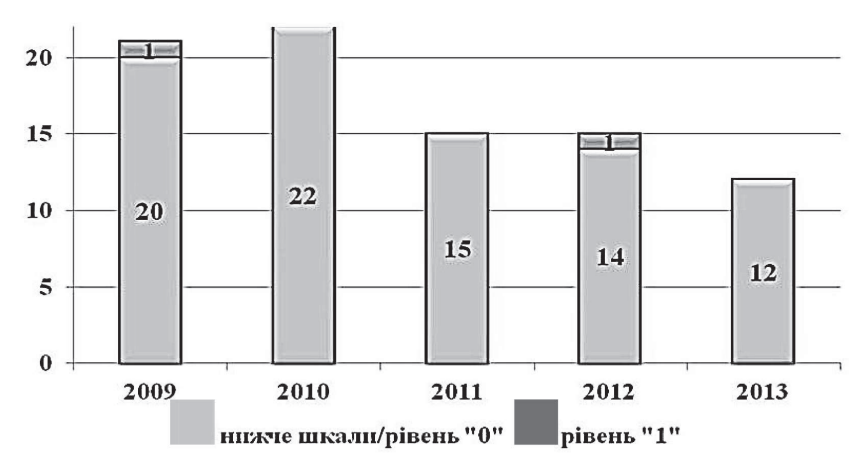

Рис. 5. Розподіл кількості порушень у роботі АЕС України за шкалою İНЕC у 2009-2013 роках

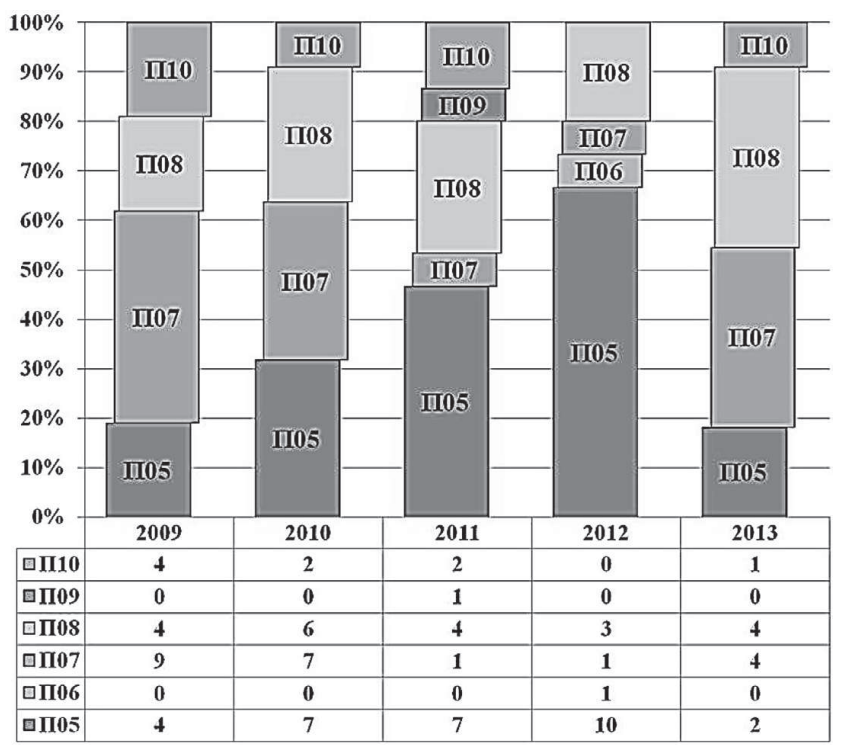

Рис. 6. Розподіл внесків у загальну кількість порушень різних категорій (категорії П05/1 та П05/2 об'єднані в одну - П05, категорії П07/1 та П07/2 - в П07)

П07 (відмови важливого для безпеки АЕС обладнання), до того ж усі 4 порушення було класифіковано категорією П07/1 - «відмови важливого для безпеки обладнання та трубопроводів, що належать до груп А і В, елементів 1-го та 2-го класів безпеки, органу регулювання системи управління та захисту (СУз) з приводним механізмом». Частка порушень категорії П08 (розвантаження енергоблока) зросла більше ніж на $25 \%$ і в 2013 році стала найбільшою за останні п’ять років. Кількість порушень категорії П10 (непрацездатність каналу системи безпеки) стабільно залишається на низькому рівні - одне порушення (9\%). Це пояснюється модернізацією систем безпеки в рамках робіт 3 підготовки енергоблоків до продовження терміну експлуатації у понадпроектний термін.

На енергоблоці № 1 ЧАЕС за цей період сталося одне порушення категорії П07/1.

Під час 11 порушень протягом 2013 року на діючих АЕС зафіксовано 15 аномальних подій (відхилення від нормального режиму експлуатації, що може бути спричинено відмовою обладнання, зовнішнім впливом, помилкою персоналу або недоліками процедур [3]).

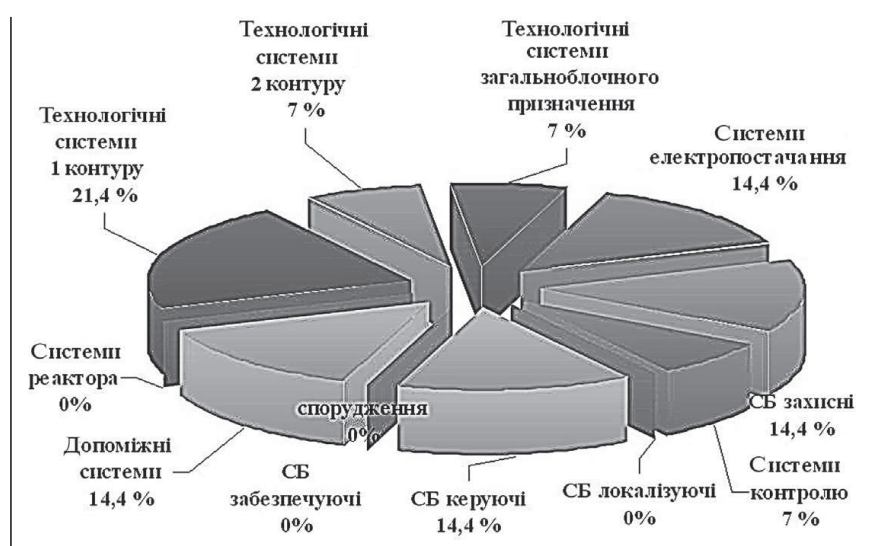

Рис. 7. Розподіл за системами, які відмовили або зазнали впливу під час аномальних подій у 2013 році

Розподіл за системами, які відмовили або зазнали впливу під час аномальних подій на діючих енергоблоках у 2013 році, наведено на рис. 7. На ЧАЕС аномальна подія сталася на системі перевантаження ядерного палива (зокрема на перевантажувальній машині).

Найбільша кількість аномальних подій (21,4 \%) пов'язана з відмовами технологічних систем 1-го контуру. Двічі відмовляли: система циркуляції теплоносія; органи управління і захисту реактора; автоматика системи управління і захисту реактора.

Аналіз елементів, які відмовили або зазнали пошкодження, та категорій персоналу, шо припустив помилку, показав, що найбільше відмов у 2013 році сталося:

на обладнанні технологічних систем - $25 \%$ (у 2012 році $-21,7 \%$ );

на обладнанні систем автоматичного управління захисту і сигналізації - $25 \%$ (у 2012 році - 17,4 \%);

на обладнанні систем електропостачання - 18,75\% (у 2012 році - 17,4 \%);

через помилки персоналу - 12,5\% (у 2012 році - 30,4\%).

Більшість відмов, на відміну від 2012 року, коли 30,4 \% припадало на помилки персоналу, сталося на обладнанні технологічних систем та систем автоматичного управління захисту і сигналізації - по $25 \%$. Позитивним фактором є зменшення в 2,4 раза відмов через помилки персоналу на відміну від 2012 року. На ЧАЕС під час аномальної події відмовили елементи обладнання розвантажувальнонавантажувальної машини.

Відповідно до класифікації [3], безпосередні причини розділені на вісім основних груп. Для 15 аномальних подій встановлено 17 безпосередніх причин.

На ЧАЕС безпосередньою причиною виникнення аномальної події було механічне ушкодження, зокрема стомленість металу конструкції, дефект зварювального шва, внутрішній дефект матеріалу.

Основними безпосередніми причинами аномальних подій за останні три роки на діючих енергоблоках були (рис. 8):

стомленість металу конструкції, дефект зварювального шва, внутрішній дефект матеріалу (3 причини - $18 \%$ );

вібрація (2 причини - $12 \%)$;

втрата сигналу, відсутність сигналу (2 причини - $12 \%)$; відсутність контролю, неякісний контроль за станом елемента, системи і виконуваними технологічними операціями (2 причини $-12 \%)$. 


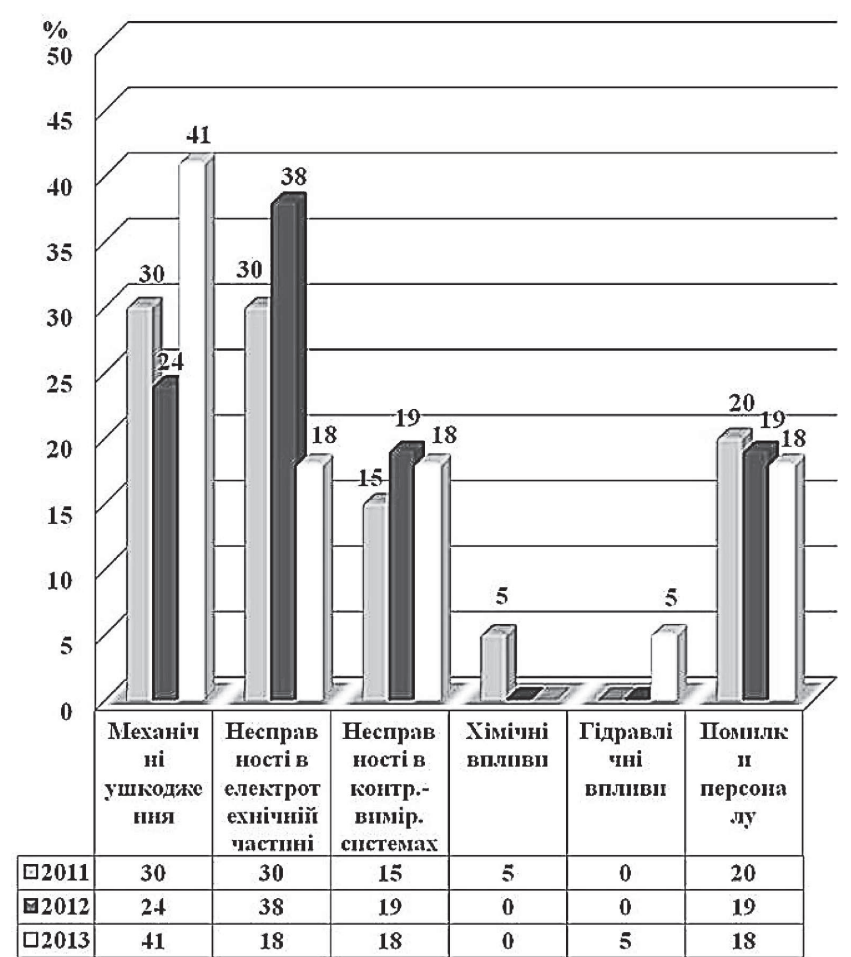

Рис. 8. Розподіл безпосередніх причин виникнення аномальних подій

Вперше за останні роки зменшилася кількість безпосередніх причин, пов'язаних з несправностями в електротехнічній частині (удвічі порівняно з 2012 роком), але різко збільшився відсоток механічних ушкоджень (41\% проти $24 \%$ у 2012 році).

Останні три роки помилки персоналу стабільно становлять п'яту частину від загальної кількості причин, що є негативним фактом і потребує ретельного розгляду експлуатуючою організацією.

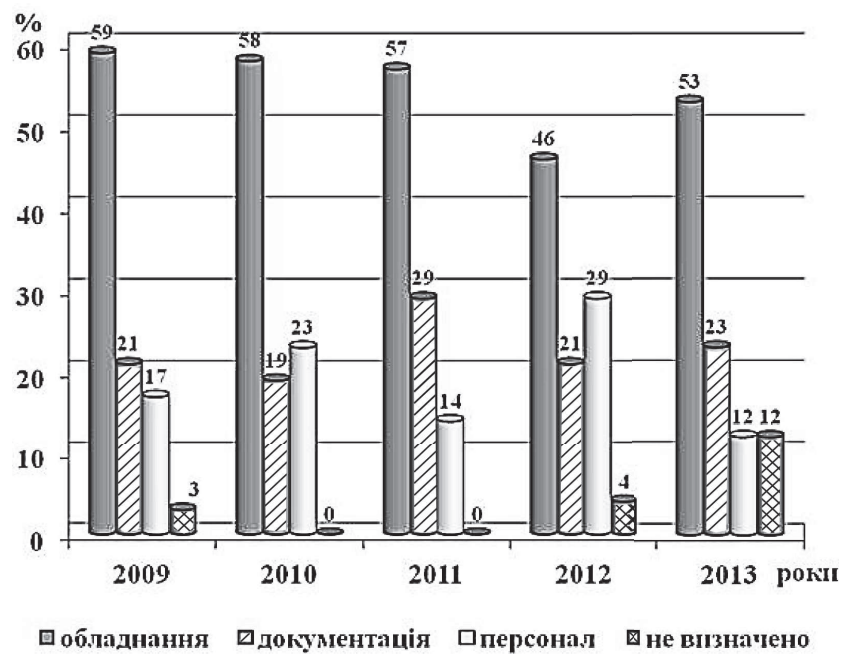

Рис. 9. Розподіл корінних причин виникнення аномальних подій
Корінні причини порушень за своїм характером діляться, відповідно до [3], на три основні групи:

корінні причини, що пов'язані з обладнанням;

корінні причини, що пов'язані з документацією;

корінні причини, що пов'язані з персоналом та системою управління.

До окремої групи виділено порушення, корінні причини яких не встановлені під час розслідування. Це зроблено з метою відстеження кількості таких порушень та акцентування уваги фахівців на цьому питанні. Внесок кожної групи корінних причин у загальну кількість порушень у 2009-2013 роках на діючих енергоблоках зображено на рис. 9. На ЧАЕС корінна причина виникнення аномальної події пов'язана з обладнанням - недоліками виготовлення.

Традиційно найбільший внесок дають причини, пов'язані з відмовами обладнання (53\%). За останній рік намітилося різке зростання (у три рази) частки корінних причин, які не визначені під час їх розслідування, шо в подальшому може призвести до виникнення аналогічних порушень. Порівняно з 2012 роком у 2,4 раза знизилася частка корінних причин, пов'язаних 3 персоналом.

Основними корінними причинами аномальних подій були:

недоліки виготовлення (3 причини $-18 \%)$;

не визначені (2 причини $-12 \%)$;

недоліки проектування (2 причини $-12 \%)$;

недоліки документації заводу-виробника (2 причини - $12 \%)$.

Оцінка правильності визначення причин порушень та адекватності призначених коригувальних заходів. Аналіз коректності встановлення причин та адекватності коригувальних заходів виконується фахівцями ДНТЦ ЯРБ у процесі розробки оперативних повідомлень. Результатом аналізу $€$ висновок про те, чи обгрунтовано встановлені причини порушення, чи адекватні коригувальні заходи призначено та чи потребує звіт з розслідування порушення доопрацювання або проведення додаткового розслідування.

За результатами оперативного аналізу всіх звітів 3 порушень за 2013 рік $44 \%$ рекомендовано направити на дорозслідування, а $12 \%$ - на доопрацювання.

У 56 \% звітів з розслідування порушень, які надійшли в ДНТЦ ЯРБ (враховуючи звіти з дорозслідування та доопрацювання), причини визначено правильно, а призначені коригувальні заходи є адекватними (рис. 10). До $12 \%$ цих звітів були незначні зауваження, через що їх було рекомендовано направити на доопрацювання. Цей показник менший на $4 \%$, ніж торік. Зауважимо, шо останні два роки намітилася позитивна тенденція щодо якості розслідування порушень порівняно з 2009-2011 роками.

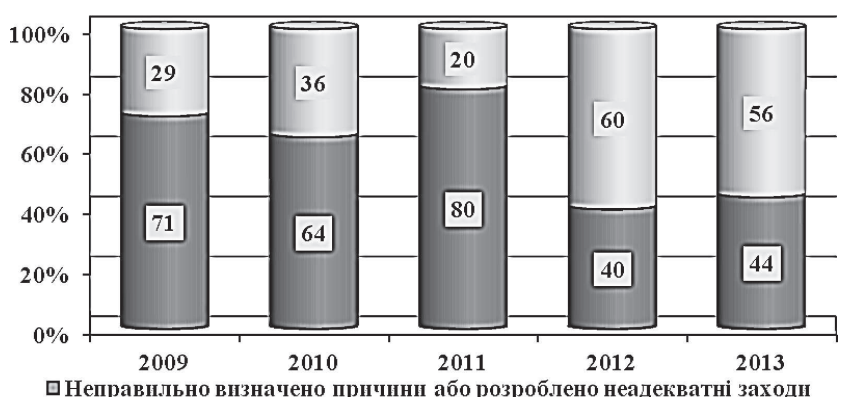

๑ Неправпльно визначено причнни або розроблено неадекватні заходи 口Правильно визнатено причнни та розроблено адекватні заходи

Рис. 10. Порівняльний аналіз ефективності роботи станційних комісій 


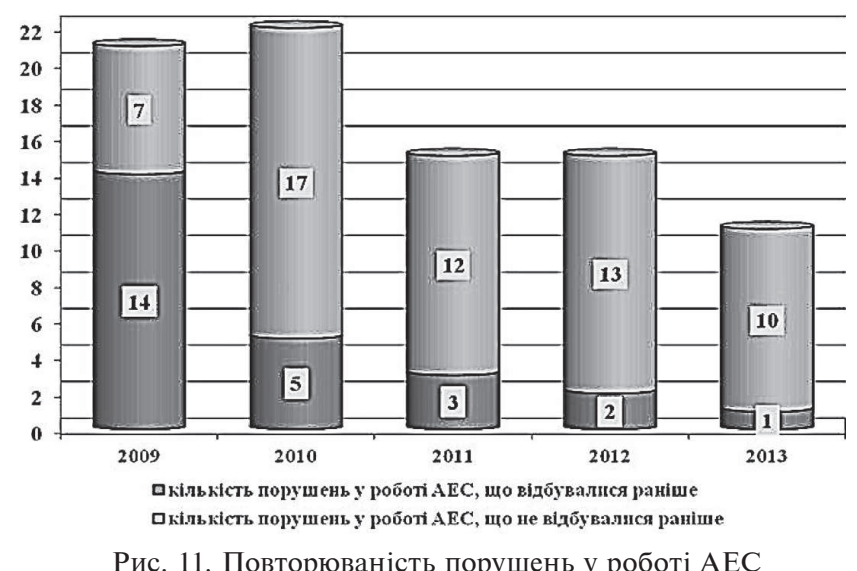

Рис. 11. Повторюваність порушень у роботі АЕС

Аналіз причин повторюваності порушень. Аналіз попередніх аналогічних порушень має полягати в розгляді причин та оцінці призначених коригувальних заходів. Причинами повторення порушення можуть бути неправильне визначення причин попереднього порушення, призначення неадекватних коригувальних заходів, несвоєчасне їх впровадження або невиконання тих коригувальних заходів, що були заплановані. Крім того, аналіз попередніх аналогічних порушень може дати важливі результати, корисні для всієї галузі. Тому такий аналіз є важливим елементом системи використання досвіду експлуатації.

У процесі оперативного аналізу звітів 3 розслідування порушень, який проводиться в ДНТЦ ЯРБ, перевіряється повнота аналізу досвіду експлуатації, який було виконано комісією під час розслідування порушення. За результатами оперативного аналізу порушень у роботі AEC, які сталися у 2013 році, зроблено одне зауваження щодо ненадання ін формації про попередні аналогічні порушення в роботі АЕС.

Зазначимо, що важливо не тільки виявити попередні аналогічні або схожі порушення (чи відхилення), а й проаналізувати причини повторення аномальних подій або перетворення супутнього фактора попередньої аномальної події в корінну причину нової. Такий підхід відповідає принципам безпеки, тому дуже важливо заохочувати персонал, який бере участь у розслідуванні порушень, до якісного виконання робіт цього напряму.

Результати аналізу повторюваності порушень у роботі AEC за звітний період порівняно з аналогічними даними за останні п'ять років здійснено на підставі звітів про розслідування порушень у роботі АЕС.

Ситуація, яка на сьогоднішній день склалася з повторенням порушень у роботі АЕС, свідчить про встановлення тенденції щодо їх зменшення (рис. 11). Проте проблеми щодо ефективності використання досвіду експлуатації, які потребують вирішення, ще існують. $\mathcal{E}$ випадки формального підходу до пошуку попередніх аналогічних порушень (або відхилень) та (або) відсутності їх аналізу.

\section{Висновки}

У 2013 році сталося 12 порушень, що є найменшим показником за останні п'ять років. На всіх діючих АЕС України кількість порушень порівняно з 2012 роком або зменшилася, або залишилася на тому самому рівні. Відбулося різке зменшення кількості аномальних подій внаслідок помилок персоналу, але кількість безпосередніх причин, які пов'язані 3 персоналом, останні три роки стабільно складають п'яту частину. Через це необхідно приділяти більшу увагу підготовці персоналу, який бере участь в експлуатації та ремонті РУ, та підвищувати рівень культури безпеки персоналу всіх рівнів.

За результатами аналізу інформації про впровадження коригувальних заходів у 2013 році, АЕС в цілому виконують коригувальні заходи, призначені за результатами розслідування порушень, однак не завжди своєчасно. Оскільки, як свідчить досвід експлуатації, це призводить до появи аналогічних порушень, важливо дотримуватися графіка впровадження коригувальних заходів.

Найбільше порушень на один енергоблок за останні п’ять років сталося на енергоблоці № 2 ХАЕС. Рекомендується проаналізувати ці порушення, виявити негативні фактори, що призвели до виникнення порушень, та розробити коригувальні заходи щодо їх усунення. Також доречним буде вивчення позитивного досвіду експлуатації енергоблока № 1 ЮУАЕС, де останні шість років не сталося жодного порушення.

Майже в половині звітів про порушення під час розслідування неправильно визначаються причини або призначаються неадекватні коригувальні заходи, що в подальшому може призвести до виникнення аналогічних порушень. Тому важливим $є$ підбір персоналу для участі в розслідуванні порушень, періодичне підтримання знань та постійне вдосконалення навичок щодо проведення аналізу експлуатаційних подій, ознайомлення 3 міжнародним досвідом, напрацюваннями інших АЕС.

\section{Список використаної літератури}

1. Звіт про науково-дослідну роботу : Оперативний та технологічний аналіз порушень у роботі АЕС України у 2013-2014 pp. : Оперативний та технологічний аналіз порушень у роботі АЕС України за 2013 рік (проміжний, етап 3) / ДНТЦ ЯРБ; керівник О. Ї. Лігоцький; викон. С. В. Недбай, Г. Г. Мелешко, Р. І̇. Серафін. - К., 2014. - 213 с. - № держреєстрації 011U004712.

2. ИНЕС: Международная шкала ядерных и радиологических событий: Руководство для пользователей : Изд-е 2008 года. Вена : МАГАТЭ, 2010. - $230 \mathrm{c}$.

3. Положення про порядок розслідування та обліку порушень в роботі атомних станцій : НП 306.2.100-2004 // Офіційний вісник України. - 2004. - № 51. - Стор. 187, ст. 3382. Код акту 31072/2004.

\section{References}

1. Lihotskyy O. I., Nedbay S. V., Meleshko G. G., Serafyn R. I. (2014), Report on R\&D "Prompt and Technological Analysis of Operational Events at Ukrainian NPPs for 2013-2014. Prompt and Technological Analysis of Operational Events at Ukrainian Nuclear Power Plants for 2013 (Intermediate, Stage 3) [Zvit pro naukovo-doslidnu robotu: Operatyvnyi ta tekhnolohichnyi analiz porushen u roboti AES Ukrainy u 2013-2014 rotsi: Operatyvnyi ta tekkhnolohichnyi analiz porushen u roboti AES Ukrainy za 2013 rik (promiznyi, etap 3)], SSTC NRS, Kyiv, 213 p., State Registration No. 011U004712. (Ukr).

2. INES: The International Nuclear and Radiological Event Scale [INES: Mezhdunarodnaia shkala yadernykh i radiologicheskikh sobytiy: Rukovodstvo dlia polvovatelei], User's Manual: 2008 Edition, Vienna, IAEA, 2010, 230 pp. (Rus).

3. NP 306.2.100-2004. Provision on Procedure for Investigation and Accounting of NPP Operational Events [Polozhennia pro poriadok rozsliduvallia ta obliku porushen $\mathrm{v}$ roboti atmnykh stantsii: NP 306.2.100-2004], Ofitsiynyi Visnyk Ukrainy, 2004, No. 51, p. 187, Art. 3382, Act code: 31072/2004. (Ukr).

Отримано 30.10.2014. 